\title{
The Effect of Psychosocial Stress on the Incidence of Hypertension in Rural and Urban Communities
}

\section{Pengaruh Stres Psikososial terhadap Kejadian Hipertensi pada Masyarakat Pedesaan dan Perkotaan}

\author{
Mira Istiana, Yeni* \\ Program Studi Ilmu Kesehatan Masyarakat Fakultas Kesehatan Masyarakat \\ Universitas Sriwijaya \\ ('yenidoanks88@gmail.com)
}

\begin{abstract}
The prevalence of hypertension in Indonesia increased to $34.1 \%$ in 2018. Hypertension incidence was higher in rural than urban. Psychosocial stress was hypertension risk factors. Individuals with psychosocial stress 3 times at risk get hypertension. The purpose was to determine effect of psychosocial stress on hypertension in rural and urban communities. A cross sectional study design with secondary data IFLS 5 in 2014. Sample was respondents of IFLS 5 who $\geq 15$ years old and had blood pressure measurement data. The sample size was 10.008 in rural and 16,057 urban. Data analysis use complex sample as secondary data analysis technique by considering weighting when analyzing data. The results showed the hypertension was $29.7 \%$ in rural and $31.3 \%$ in urban. In rural, psychosocial stress increases the risk of hypertension after being controlled for age, sex, education, economic, marital status and $\mathrm{BMI}(\mathrm{PR}=1,108 ; 95 \% \mathrm{CI}=1,016-1,209)$. In urban, psychosocial stress increases the risk of hypertension after being controlled by age, sex, education, economic, marital status, $\mathrm{BMI}$ and tobacco consumption $(\mathrm{PR}=1,174 ; 95 \% \mathrm{CI}=1,032$ 1,335). Psychosocial stress was a risk factor for hypertension. The importance of providing hypertension prevention education such as stress management techniques to prevent hypertension in integrated assistance post (Posbindu). Keywords: Psychosocial stress, hypertension, rural, urban
\end{abstract}

\section{ABSTRAK}

Prevalensi hipertensi di Indonesia meningkat menjadi 34,1\% tahun 2018. Kejadian hipertensi lebih tinggi pada masyarakat pedesaan dibanding perkotaan. Faktor risiko hipertensi antara lain stres psikososial. Individu dengan stres psikososial berisiko 3 kali lebih besar menderita hipertensi. Tujuan penelitian mengetahui pengaruh stres psikososial terhadap hipertensi pada masyarakat pedesaan dan perkotaan. Desain penelitian cross sectional dengan data sekunder IFLS 5 tahun 2014. Sampel penelitian adalah responden IFLS 5 yang berusia $\geq 15$ tahun dan memiliki data pengukuran tekanan darah. Besar sampel sebanyak 10.008 responden pedesaan dan 16.057 responden perkotaan. Analisis data menggunakan complex sample analysis yaitu teknik analisis data sekunder dengan mempertimbangkan pembobotan pada saat analisa data. Hasil menunjukkan prevalensi hipertensi sebanyak 29,7\% di pedesaan dan 31,3\% di perkotaan. Pada masyarakat pedesaan, stres psikososial meningkatkan risiko hipertensi setelah dikontrol variabel usia, jenis kelamin, status pendidikan, status ekonomi, status perkawinan dan IMT (PR=1,108; 95\% CI=1,016-1,209). Pada masyarakat perkotaan, stres psikososial meningkatkan risiko hipertensi setelah dikontrol variabel usia, jenis kelamin, status pendidikan, status ekonomi, status perkawinan, IMT dan konsumsi tembakau (PR=1,174; 95\% CI=1,0321,335). Stres psikososial adalah faktor risiko hipertensi. Pentingnya memberikan edukasi pencegahan hipertensi seperti teknik manajemen stres sebagai bagian dari upaya mencegah hipertensi pada program Posbindu. Kata kunci: Stres psikososial, hipertensi, pedesaan, perkotaan 


\section{INTRODUCTION}

Hypertension is the first rank for cause of death every year, as the World Health Organization estimates 1.13 billion sufferers worldwide, which is predicted to affect about 1.5 billion adults in 2025. The prevalence of patients in Southeast Asia amongst the age group of $>18$ years is estimated at $25.3 \%$ male and $24.2 \%$ female. ${ }^{1}$ Furthermore, the basic Health Research in 2018 showed an increase in the prevalence of non-communicable diseases, encompassing cancer, stroke, chronic kidney disease, diabetes mellitus, and hypertension compared with data collected in 2013. Specifically, the prevalence of hypertension in Indonesia, which was obtained through measurements in the age group of $\geq 18$ years increased from $25.8 \%$ in 2013 to $34.1 \%$ in 2018. This information was obtained through the questionnaire, including individuals diagnosed by health professionals $(8.4 \%)$ and those currently taking medication $(8.8 \%){ }^{2}$

The epidemiology of cardiovascular diseases driven by demographic and socioeconomic changes, which affect life habits, increases the risk of hypertension, including mental stress (psychosocial stress), tobacco consumption, physical activity, obesity and various dietary patterns. ${ }^{3}$ A previous study by Peltzer and Pengpid showed a 1.17 times greater risk in individuals experiencing from depressive symptoms, than otherwise. ${ }^{4}$ Eashwar, et al established the presence a significant relationship between the psychosocial stress variables (depression, anxiety and stress) and the 3 times greater risk of suffering hypertension. Hence, the concurrent occurrence of stress and anxiety lead to uncontrolled hypertension. ${ }^{5}$

Previous research reported that the contribution of urbanization factor, due to the effects on lifestyle patterns, characterized by a decline in physical activity, changes in diet and increased stress levels. ${ }^{6,7}$ Furthermore, some researches have demonstrated a higher incidence amongst the rural than urban communities, ${ }^{6}$ while other reported on the 1.4 times greater at risk of suffering from stress in urban areas. ${ }^{8}$ This was congruent with data obtained in Indonesia from the Basic Health Research, through measurements at $26.1 \%$, compared to the rural areas, which recorded $25.5 \% .^{2}$ Therefore, this study is aimed at determining the effect of psychosocial stress on the incidence of hyperten- sion in rural and urban communities of Indonesia.

\section{MATERIALS AND METHODS}

This is a quantitative study with cross sectional study design, use secondary data obtained from IFLS 5 in 2014. The sampling method was performed according to the technique in the IFLS 5 Survey data, characterized by multistage random sampling, therefore consisting of all previous respondents. Furthermore, the inclusion criteria comprises individuals aged $\geq 15$ years with a blood pressure measurement data, which was fulfilled by 10,008 and 26,065 respondents for rural and urban communities, respectively. The information obtained were evaluated using a complex sample analysis approach, which is commonly used on secondary data processing of survey results, on instances where simple random sampling was not used. This was performed by considering the weight of each analysis performed, with the intention of providing similar chances to choose a sample, subsequently ensuring the production of more accurate results. In addition, chi-square test for complex samples was the statistical tool adopted at the bivariate stage, while multiple logistic regression was used at the multivariate stage, followed by the presentation of research data in tabular and narrative forms.

Thedependentvariableis thehistoryof hypertension in respondents, which was grouped into two, encompassing present and absent. The respondents were reported to suffer from hypertension on instances where one or all of the following conditions are fulfilled, including an average blood pressure of $\geq 140 / 90 \mathrm{mmhg}$ after 3 times measurement, history of illness or taking affiliated medication. Conversely, the main independent variable was psychosocial stress, confirmed to be present when all of the following conditions are fulfilled; a total score of psychological conditions $\geq 10$, life satisfaction within the satisfied category and active participation in society.

\section{RESULTS}

The proportion of respondents with hypertension was $29.7 \%$ and $31.4 \%$ for rural and urban areas, with the proportion experiencing psychosocial stress being $13.4 \%$ and $11 \%$, respectively. In addition, majorities in rural areas $(63.7 \%)$ were 
Table 1. Frequency Distribution of Respondents Characteristics in Rural and Urban Areas

\begin{tabular}{|c|c|c|c|c|}
\hline \multirow{2}{*}{ Variable } & \multicolumn{2}{|c|}{ Rural } & \multicolumn{2}{|c|}{ Urban } \\
\hline & $n=10.008$ & $\%$ & $n=16.057$ & $\%$ \\
\hline \multicolumn{5}{|l|}{ Hypertension Incidence } \\
\hline Yes & 2.969 & 29,7 & 5.027 & 31,3 \\
\hline No & 7.039 & 70,3 & 11.030 & 68,7 \\
\hline \multicolumn{5}{|l|}{ Psychosocial Stress } \\
\hline Yes & 1.338 & 13,4 & 1.764 & 11 \\
\hline No & 8.670 & 86,6 & 14.293 & 89 \\
\hline \multicolumn{5}{|l|}{ Age } \\
\hline$\geq 65$ years old & 691 & 6,9 & 902 & 5,6 \\
\hline $45-64$ years old & 2.946 & 29,4 & 4.910 & 30,6 \\
\hline $15-44$ years old & 6.371 & 63,7 & 10.245 & 63,8 \\
\hline \multicolumn{5}{|l|}{ Gender } \\
\hline Male & 4.916 & 49,1 & 7.638 & 47,6 \\
\hline Female & 5.092 & 50,9 & 8.419 & 52,4 \\
\hline \multicolumn{5}{|l|}{ Education Status } \\
\hline No school & 626 & 6,3 & 423 & 2,6 \\
\hline School & 9328 & 93,7 & 15.634 & 97,4 \\
\hline \multicolumn{5}{|l|}{ Economic Status } \\
\hline Low & 4.230 & 42,3 & 6.485 & 40,4 \\
\hline High & 5.778 & 57,7 & 9.572 & 59,6 \\
\hline \multicolumn{5}{|l|}{ Marital Status } \\
\hline Widower / widow & 884 & 8,8 & 1.435 & 8,9 \\
\hline Marry & 7.673 & 76,7 & 11.408 & 71 \\
\hline Single & 1.451 & 14,5 & 3.214 & 20 \\
\hline \multicolumn{5}{|l|}{ Job Status } \\
\hline Does not work & 3.276 & 32,7 & 5.565 & 34,7 \\
\hline Work & 6.732 & 67,3 & 10.492 & 65,3 \\
\hline \multicolumn{5}{|l|}{ Body mass index } \\
\hline Obesity & 639 & 6,4 & 1.528 & 9,5 \\
\hline Overweight & 2.144 & 21,4 & 4.294 & 26,7 \\
\hline Normal & 5.902 & 59 & 8.478 & 52,8 \\
\hline Low Weight & 1.323 & 13,2 & 1.757 & 10,9 \\
\hline \multicolumn{5}{|l|}{ Physical Activity } \\
\hline Less & 4.451 & 44,5 & 8.251 & 51,4 \\
\hline Enough & 5.557 & 55,5 & 7.806 & 48,6 \\
\hline \multicolumn{5}{|c|}{ Tobacco Consumption History } \\
\hline Yes & 3.499 & 35 & 4.767 & 29,7 \\
\hline Ever & 444 & 4,4 & 846 & 5,3 \\
\hline Never & 6.065 & 60,6 & 10.444 & 65 \\
\hline \multicolumn{5}{|l|}{ Fat Consumption } \\
\hline Often & 5.741 & 57,4 & 7.332 & 45,7 \\
\hline Rarely & 4.267 & 42,6 & 8.725 & 54,3 \\
\hline
\end{tabular}

Source: Secondary Data of IFLS 5, 2014

aged 15 to 44 years, $57.7 \%$ had a high economic status, $50.9 \%$ were women, $76.7 \%$ had a married status, $67.3 \%$ were workers, and $59 \%$ had normal BMI status. Conversely, most of the respondents in urban areas $(63.8 \%)$ were aged 15 to 44 years,
$59.6 \%$ had high economic status, $52.4 \%$ were women. Also, other characteristics include married status $(71 \%)$, workers $(65.3 \%)$, and normal BMI status (52.8\%). Furthermore, respondents in the rural areas (55.5\%) engaged in sufficient 
Table 2. Risk Factors of Hypertension Incidence in the Rural Areas

\begin{tabular}{|c|c|c|c|c|c|c|c|c|}
\hline \multirow{3}{*}{ Variable } & \multicolumn{4}{|c|}{ Hypertension } & \multirow{2}{*}{\multicolumn{2}{|c|}{ Total }} & \multirow{3}{*}{ p value } & \multirow{3}{*}{$\begin{array}{c}\text { PR } \\
(95 \% \text { CI })\end{array}$} \\
\hline & \multicolumn{2}{|c|}{ Yes } & \multicolumn{2}{|c|}{ No } & & & & \\
\hline & $\mathbf{n}$ & $\%$ & n & $\%$ & $\mathbf{n}$ & $\%$ & & \\
\hline \multicolumn{9}{|l|}{ Psychosocial Stress } \\
\hline Yes & 454 & 34 & 884 & 66 & 1.338 & 100 & $<0,001$ & $1,17(1,12-1,22)$ \\
\hline No & 2.515 & 29 & 6.155 & 71 & 8.670 & 100 & & \\
\hline \multicolumn{9}{|l|}{ Age } \\
\hline$\geq 65$ years old & 464 & 67,1 & 227 & 32,9 & 691 & 100 & $<0,001$ & $9,32(8,11-10,71)$ \\
\hline 45-64 years old & 1.361 & 46,2 & 1.585 & 53,8 & 2.946 & 100 & $<0,001$ & $3,92(3,59-4,28)$ \\
\hline 15-44 years old & 1.144 & 18 & 5.227 & 82 & 6.371 & 100 & - & Reference \\
\hline \multicolumn{9}{|l|}{ Gender } \\
\hline Male & 1.380 & 28,1 & 3.536 & 71,9 & 4.916 & 100 & $<0,001$ & $0,89(1,80-1,99)$ \\
\hline Female & 1.590 & 31,2 & 3.502 & 68,8 & 5.092 & 100 & & \\
\hline \multicolumn{9}{|l|}{ Education Status } \\
\hline No school & 333 & 53,2 & 293 & 46,8 & 626 & 100 & $<0,001$ & $1,89(1,80-1,99)$ \\
\hline School & 2.636 & 28,1 & 6.746 & 71,9 & 9.382 & 100 & & \\
\hline \multicolumn{9}{|l|}{ Job Status } \\
\hline Does not work & 932 & 28,4 & 2.334 & 71,6 & 3.276 & 100 & 0,031 & $0,94(0,88-0,99)$ \\
\hline Work & 2.038 & 30,3 & 4.694 & 69,7 & 6.732 & 100 & & \\
\hline \multicolumn{9}{|l|}{ Marital Status } \\
\hline Widower / widow & 470 & 53,1 & 414 & 46,9 & 884 & 100 & $<0,001$ & $8,24(7,03-9,65)$ \\
\hline Marry & 2.324 & 30,3 & 5.349 & 69,7 & 7.673 & 100 & $<0,001$ & $3,16(2,75-3,63)$ \\
\hline Single & 176 & 12,1 & 1.275 & 87,9 & 1.451 & 100 & - & Reference \\
\hline \multicolumn{9}{|l|}{ Economic Status } \\
\hline Low & 1.280 & 30,3 & 2.950 & 69,7 & 4.230 & 100 & 0,184 & $1,03(0,98-1,09)$ \\
\hline High & 1.689 & 29,2 & 4.089 & 70,8 & 5.778 & 100 & & \\
\hline \multicolumn{9}{|l|}{ Body mass index } \\
\hline Obesity & 321 & 50,3 & 318 & 49,7 & 639 & 100 & $<0,001$ & $2,94(2,56-3,37)$ \\
\hline Overweight & 864 & 40,3 & 1.280 & 59,7 & 2.144 & 100 & $<0,001$ & $1,96(1,81-2,12)$ \\
\hline Normal & 1.512 & 25,6 & 4.390 & 74,4 & 5.902 & 100 & - & Reference \\
\hline Low Weight & 271 & 20,5 & 1.052 & 79,5 & 1.323 & 100 & $<0,001$ & $0,75(0,68-0,82)$ \\
\hline \multicolumn{9}{|l|}{ Physical Activity } \\
\hline Less & 1.310 & 29,4 & 3.141 & 70,6 & 4.451 & 100 & 0,530 & $0,98(0,94-1,03)$ \\
\hline Enough & 1.660 & 29,9 & 3.897 & 70,1 & 5.557 & 100 & & \\
\hline \multicolumn{9}{|l|}{ Fat Consumption } \\
\hline Often & 0,985 & 31,5 & 3.933 & 68,5 & 5.741 & 100 & $<0,001$ & $1,16(1,10-1,21)$ \\
\hline Rarely & 1.161 & 27,2 & 3.106 & 72,8 & 4.267 & 100 & & \\
\hline
\end{tabular}

Source: Secondary Data of IFLS 5, 2014

physical activity, did not have a history of tobacco consumption (60.6\%), and often consume fat by $57.4 \%$, which was $51.4 \% 65 \%$, and $54.3 \%$, respectively for the urban community (Table 1).

A significant relationship was established between psychosocial stress, age, sex, education, job, and marital status, body mass index, as well as history of tobacco and fat consumption, with the hypertension incidence in rural areas (Table 2), while a similar correlation was observed in the urban community, with the addition of economic status (Table 3).

Therefore, psychosocial stress is strongly affiliated with the incidence of hypertension, due to the control variables of age, gender, education status, economic status, marital status and body mass index (BMI) in the rural community, with the PR adjusted value of 1.108 (95\% CI 1.016-1.209) (Table 4). Conversely, a similar association was established in the urban community, following the aforementioned variables, alongside history of tobacco consumption, with a PR adjusted value of 
Table 3. Risk Factors of Hypertension Incidence in the Urban Areas

\begin{tabular}{|c|c|c|c|c|c|c|c|c|}
\hline \multirow{3}{*}{ Variable } & \multicolumn{4}{|c|}{ Hypertension } & \multirow{2}{*}{\multicolumn{2}{|c|}{ Total }} & \multirow{3}{*}{ p value } & \multirow{3}{*}{$\begin{array}{c}\text { PR } \\
(95 \% \text { CI })\end{array}$} \\
\hline & \multicolumn{2}{|c|}{ Yes } & \multicolumn{2}{|c|}{ No } & & & & \\
\hline & $\mathbf{n}$ & $\%$ & $\mathbf{n}$ & $\%$ & $\mathbf{n}$ & $\%$ & & \\
\hline \multicolumn{9}{|l|}{ Psychosocial Stress } \\
\hline Yes & 601 & 34,1 & 1.163 & 65,9 & 1.764 & 100 & 0,022 & $1,10(1,01-1,19)$ \\
\hline No & 4.426 & 31 & 9.867 & 69 & 14.293 & 100 & & \\
\hline \multicolumn{9}{|l|}{ Age } \\
\hline$\geq 65$ years old & 631 & 70 & 271 & 30 & 902 & 100 & $<0,001$ & $10,74(9,03-12,77)$ \\
\hline 45-64 years old & 2.570 & 52,3 & 2.340 & 47,7 & 4.910 & 100 & $<0,001$ & $5,07(4,68-5,48)$ \\
\hline 15-44 years old & 1.826 & 17,8 & 8.419 & 82,2 & 10.245 & 100 & - & Reference \\
\hline \multicolumn{9}{|l|}{ Gender } \\
\hline Male & 2.296 & 30,1 & 5.342 & 69,9 & 7.638 & 100 & $<0,001$ & $0,92(0,89-0,97)$ \\
\hline Female & 2.731 & 32,4 & 5.688 & 67,6 & 8.419 & 100 & & \\
\hline \multicolumn{9}{|l|}{ Educational Status } \\
\hline No school & 249 & 59 & 173 & 41 & 422 & 100 & $<0,001$ & $1,93(1,70-2,19)$ \\
\hline School & 4.778 & 30,6 & 10.857 & 69,4 & 15.635 & 100 & & \\
\hline \multicolumn{9}{|l|}{ Job Status } \\
\hline Does not work & 1.828 & 32,8 & 3.737 & 67,2 & 5.565 & 100 & 0,005 & $1,08(1,02-1,13)$ \\
\hline Work & 3.199 & 30,5 & 7.293 & 69,5 & 10.492 & 100 & & \\
\hline \multicolumn{9}{|l|}{ Marital Status } \\
\hline Widower / widow & 789 & 55 & 646 & 45 & 1.435 & 100 & $<0,001$ & $8,57(7,46-9,85)$ \\
\hline Marry & 3.836 & 33,6 & 7.572 & 66,4 & 11.408 & 100 & $<0,001$ & $3,55(3,18-3,96)$ \\
\hline Single & 401 & 12,5 & 2.813 & 87,5 & 3.214 & 100 & - & Reference \\
\hline \multicolumn{9}{|l|}{ Economic Status } \\
\hline Low & 2.183 & 33,7 & 4.302 & 66,3 & 6.485 & 100 & $<0,001$ & $1,13(1,08-1,19)$ \\
\hline High & 2.844 & 29,7 & 6.728 & 70,3 & 9.572 & 100 & & \\
\hline \multicolumn{9}{|l|}{ Body mass index } \\
\hline Obesity & 791 & 51,8 & 737 & 48,2 & 1.528 & 100 & $<0,001$ & $3(2,69-3,34)$ \\
\hline Overweight & 1.766 & 41,1 & 2.528 & 58,9 & 4.294 & 100 & $<0,001$ & $1,95(1,79-2,13)$ \\
\hline Normal & 2.233 & 26,3 & 6.245 & 73,7 & 8.478 & 100 & - & Reference \\
\hline Low Weight & 237 & 13,5 & 1.520 & 86,5 & 1.757 & 100 & $<0,001$ & $0,44(0,36-0,53)$ \\
\hline \multicolumn{9}{|l|}{ Physical Activity } \\
\hline Less & 2.599 & 31,5 & 5.652 & 68,5 & 8.251 & 100 & 0,642 & $1,01(0,96-1,07)$ \\
\hline Enough & 2.428 & 31,1 & 5.378 & 68,9 & 7.806 & 100 & & \\
\hline \multicolumn{9}{|l|}{ Tobacco Consumption } \\
\hline \multicolumn{9}{|l|}{ History } \\
\hline Yes & 1.345 & 28,2 & 3.422 & 71,8 & 4.767 & 100 & $<0,001$ & $0,86(0,80-0,93)$ \\
\hline Ever & 417 & 49,3 & 429 & 50,7 & 846 & 100 & $<0,001$ & $2,14(1,83-2,47)$ \\
\hline Never & 3.265 & 31,3 & 7.179 & 68,7 & 10.444 & 100 & - & Reference \\
\hline \multicolumn{9}{|l|}{ Fat Consumption } \\
\hline Often & 2.552 & 34,8 & 4.780 & 65,2 & 7.332 & 100 & $<0,001$ & $1,23(1,16-1,29)$ \\
\hline Rarely & 2.475 & 28,4 & 6.250 & 71,6 & 8.725 & 100 & & \\
\hline
\end{tabular}

Source: Secondary Data of IFLS 5, 2014

1.174 (95\% CI 1.032-1.335) (Table 5).

\section{DISCUSSION}

The results of multivariate analysis in rural communities showed the significant influence of psychosocial stress variables on the incidence of hypertension, due to the control variables of age, sex, education, economic and marital status, as well as BMI. Therefore, cause a 1,108 times greater risk. Meanwhile, a similar correlation was also observed in urban communities, based on the aforementioned variables, alongside history of tobacco consumption. Hence, people suffering from psychosocial stress have a 1.174 times greater risk 
Table 4. Multivariate Analysis: The Relationship of Psychosocial Stress with the Hypertension Incidence after being controlled by Confounding Variables in Rural Areas

\begin{tabular}{|c|c|c|c|c|c|c|c|c|}
\hline \multirow{2}{*}{ Variable } & \multirow{2}{*}{$p$ value } & \multirow{2}{*}{$\begin{array}{c}\text { PR } \\
\text { Crude }\end{array}$} & \multicolumn{2}{|c|}{ 95\% CI } & \multirow{2}{*}{ p value } & \multirow{2}{*}{$\begin{array}{c}\text { PR } \\
\text { Adjusted }\end{array}$} & \multicolumn{2}{|c|}{$95 \%$ CI } \\
\hline & & & Lower & Upper & & & Lower & Upper \\
\hline Psychosocial Stress & 0,016 & 1,114 & 1,021 & 1,216 & 0,021 & 1,108 & 1,016 & 1,209 \\
\hline \multicolumn{9}{|l|}{ Age } \\
\hline$\geq 65$ years old & $<0,001$ & 9,835 & 8,346 & 11,589 & $<0,001$ & 9,834 & 8,386 & 11,531 \\
\hline 45-64 years old & $<0,001$ & 3,563 & 3,224 & 3,937 & $<0,001$ & 3,596 & 3,250 & 3,979 \\
\hline $15-44$ years old & - & - & - & - & - & Reference & - & - \\
\hline Gender & $<0,001$ & 1,204 & 1,090 & 1,330 & 0,005 & 1,151 & 1,044 & 1,269 \\
\hline Educational Status & $<0,001$ & 1,185 & 1,084 & 1,294 & $<0,001$ & 1,190 & 1,091 & 1,297 \\
\hline Economic Status & 0,005 & 1,192 & 1,054 & 1,348 & $<0,001$ & 1,194 & 1,099 & 1,297 \\
\hline \multicolumn{9}{|l|}{ Marital Status } \\
\hline Widower / widow & $<0,001$ & 2,074 & 1,712 & 2,514 & $<0,001$ & 2,072 & 1,711 & 2,509 \\
\hline Marry & $<0,001$ & 1,430 & 1,227 & 1,667 & $<0,001$ & 1,437 & 1,231 & 1,678 \\
\hline Single & - & - & - & - & - & Reference & - & - \\
\hline Job Status & 0,917 & 0,994 & 0,881 & 1,121 & - & - & - & - \\
\hline \multicolumn{9}{|l|}{ BMI } \\
\hline Obesity & $<0,001$ & 6,746 & 5,732 & 7,939 & $<0,001$ & 3,834 & 3,309 & 4,441 \\
\hline Overweight & $<0,001$ & 2,164 & 1,998 & 2,344 & $<0,001$ & 2,171 & 2,001 & 2,355 \\
\hline Normal & - & - & - & - & - & Reference & - & - \\
\hline Low Weight & $<0,001$ & 0,567 & 0,513 & 0,627 & $<0,001$ & 0,566 & 0,512 & 0,625 \\
\hline Physical Activity & 0,043 & 0,926 & 0,860 & 0,998 & - & - & - & - \\
\hline \multicolumn{9}{|l|}{ Tobacco Consumption } \\
\hline History & & & & & & & & \\
\hline Yes & 0,026 & 0,899 & 0,820 & 0,987 & - & - & - & - \\
\hline Ever & 0,124 & 1,116 & 0,970 & 1,284 & - & - & - & - \\
\hline Never & - & - & - & - & & Reference & - & - \\
\hline Fat Consumption & 0,055 & 1,059 & 0,999 & 1,124 & - & - & - & - \\
\hline
\end{tabular}

Source: Secondary Data of IFLS 5, 2014

of experiencing hypertension. The study outcome supports the previous report by Peltzer and Pengpid, which attributed a 1.17 times more significant risk to psychosocial stress obtained from depressive symptoms. ${ }^{4}$ In addition, there is also substantial correlation with depression, anxiety and stress, collectively by a 3 times greater chance, ${ }^{5}$ which was 2.2 times for individuals experiencing mental emotional disorders (stress). ${ }^{9}$

The results presents psychosocial stress as an influential factor on the incidence of hypertension in both rural and urban communities, at a proportion of $13.4 \%$, and $11 \%$, respectively. Furthermore, psychosocial stress refers to any social condition in the form of events that cause changes in a person's life, followed by indirect adaptation to overcome the stressors. This is possibly interpreted as a form of reaction in the individuals' body to of mental stress, as well as the burden of life. ${ }^{10}$ Conversely, stress is a condition that results from transactions with the environment, subsequently leading to the perception of distance between the demands of a situation with biological, psychological and social system resources. These bodily responses to stressors, danger or challenges originate with an initial reaction in the hypothalamus, followed by chain reactions that occur through nerve fibers and biochemical reactions, and subsequently through the sympathetic autonomic nervous system. This, therefore, causes various modifications throughout the body, and the ultimate increase in blood pressure. ${ }^{11}$

The risk of hypertension increases with the occurrence of psychosocial stress, which is observed to be higher in urban than rural communities, specifically characterized by the presence of closer family relationships. This is usually the basis of rural life systems, as against the more individualistic urban lifestyle, featuring the occurrence of interactions that are based on factors of 
Table 5. Multivariate Analysis: The Relationship of Psychosocial Stress with the Hypertension Incidence after being controlled by Confounding Variables in Urban Areas

\begin{tabular}{|c|c|c|c|c|c|c|c|c|}
\hline \multirow{2}{*}{ Variable } & \multirow{2}{*}{ p value } & \multirow{2}{*}{$\begin{array}{c}\text { PR } \\
\text { Crude }\end{array}$} & \multicolumn{2}{|c|}{$95 \% \mathrm{CI}$} & \multirow{2}{*}{ p value } & \multirow{2}{*}{$\begin{array}{c}\text { PR } \\
\text { Adjusted }\end{array}$} & \multicolumn{2}{|c|}{$95 \% \mathrm{CI}$} \\
\hline & & & Lower & Upper & & & Lower & Upper \\
\hline Psychosocial Stress & 0,018 & 1,169 & 1,028 & 1,330 & 0,015 & 1,174 & 1,032 & 1,335 \\
\hline \multicolumn{9}{|l|}{ Age } \\
\hline$\geq 65$ years old & $<0,001$ & 8,722 & 7,213 & 10,546 & $<0,001$ & 8,801 & 7,278 & 10,643 \\
\hline $45-64$ years old & $<0,001$ & 4,023 & 3,693 & 4,382 & $<0,001$ & 4,043 & 3,711 & 4,404 \\
\hline $15-44$ years old & - & - & - & - & - & Reference & - & - \\
\hline Gender & $<0,001$ & 1,337 & 1,182 & 1,512 & $<0,001$ & 1,339 & 1,184 & 1,515 \\
\hline Educational Status & 0,005 & 1,451 & 1,121 & 1,878 & 0,003 & 1,469 & 1,140 & 1,892 \\
\hline Economic Status & 0,008 & 1,289 & 1,068 & 1,556 & $<0,001$ & 1,280 & 1,169 & 1,401 \\
\hline \multicolumn{9}{|l|}{ Marital Status } \\
\hline Widower / widow & $<0,001$ & 2,049 & 1,748 & 2,401 & $<0,001$ & 2,068 & 1,760 & 2,431 \\
\hline Marry & $<0,001$ & 1,539 & 1,369 & 1,729 & $<0,001$ & 1,551 & 1,380 & 1,743 \\
\hline Single & - & - & - & - & - & Reference & - & - \\
\hline Job Status & 0,897 & 0,987 & 0,812 & 1,200 & - & - & - & - \\
\hline \multicolumn{9}{|l|}{ BMI } \\
\hline Obesity & $<0,001$ & 3,265 & 2,895 & 3,682 & $<0,001$ & 3,271 & 2,900 & 3,690 \\
\hline Overweight & $<0,001$ & 1,855 & 1,690 & 2,037 & $<0,001$ & 1,855 & 1,690 & 2,036 \\
\hline Normal & - & - & - & - & - & Reference & - & - \\
\hline Low Weight & $<0,001$ & 0,462 & 0,373 & 0,572 & $<0,001$ & 0,463 & 0,374 & 0,574 \\
\hline Physical Activity & 0,555 & 1,026 & 0,942 & 1,118 & - & - & - & - \\
\hline \multicolumn{9}{|l|}{ Tobacco Consumption } \\
\hline \multicolumn{9}{|l|}{ History } \\
\hline Yes & 0,036 & 0,873 & 0,770 & 0,991 & 0,036 & 0,874 & 0,771 & 0,991 \\
\hline Ever & 0,015 & 1,305 & 1,053 & 1,618 & 0,016 & 1,306 & 1,052 & 1,620 \\
\hline Never & - & - & - & - & - & Reference & - & - \\
\hline Fat Consumption & 0,068 & 1,080 & 0,994 & 1,172 & - & - & - & - \\
\hline
\end{tabular}

Source: Secondary Data of IFLS 5, 2014

interest and social change. Furthermore, the observed modifications tend to ensue quickly, consequently leading to conflicts between groups, therefore causing hurt emotions and feeling, as well as disappointment and discomfort. Particularly, urban environments are characterized by congestion, pollution, crime and urbanization, which collectively influence the lifestyle, living demands, socioeconomic status and community dietary pattern, subsequently increasing the risk of psychosocial stress. ${ }^{12}$

Age is a closely related trigger for hypertension incidence, which increases along at the exponent of time, due to natural changes in the body that affect the heart, blood vessels and hormones. ${ }^{13}$ Therefore, the resulting decline in all aspects consequently affects social life and become a source of psychosocial stress. This interferes with the function of parasympathetic and sympathetic nerves, smooth muscles, external and internal se- cretions, as well as individual awareness, which further increases the disease risk. ${ }^{14}$

Men are known to be more prone to hypertension than women, although the case tends to be reversed of both possess similar risk at the age of 45-64 years. This probability increases in women at menopause, resulting from hormonal factors ${ }^{15}$ while men are generally more exposed to unsafe behaviors, including stress, alcohol and tobacco consumption. In addition, women behave differently by paying more often visits to health services, therefore providing greater opportunities for treatment. ${ }^{16}$ Specifically, older men tend to be exposed to more stress, which is possibly caused by various factors, e.g., job modification (retirement and unemployment), and economic factors, characterized by the requirement to seek income necessary to fulfill personal and family needs. ${ }^{17}$

Other factors influencing the incidence of psychosocial stress include low level of education 
and high socioeconomic burden ${ }^{14}$ which impacts on knowledge in understanding of a problem, leading to stress resulting from the limited information obtained. ${ }^{18}$ This effect is influenced by the presence of a gap between rural and urban areas, which is caused by various aspects, including access to school locations, facilities and infrastructure, as well as sources of teaching staff. This research established a correlation between an increase in the risk of hypertension with educational status, which was greater in urban than rural areas. Furthermore, the results indicated the inability for easy access, supporting infrastructures and adequate teaching staff to guarantee the acquisition of sufficient knowledge and the application of good behavior in urban communities, according to the theory of Lehendroff and Tracy's in Vito, et al which the influence of ability and will on an individuals' behavior. ${ }^{19}$

Financial problems and household needs have also been associated with stress, which is why people with high economic remuneration and a fixed income find it difficult managing finances properly. This occurs because of the increasing needs, which becomes a burden on the mind, subsequently causing stress. ${ }^{20}$ Hence, the differences in economic status of individuals is seen from the propensity of homogeneity in rural communities, compared to the urban. ${ }^{12}$ Based on this study outcome the risk of hypertension is greater in urban areas because of the relatively higher consumptive behavior, and more attention paid to lifestyle desires associated with prestige, as against the prioritization of basic needs in rural areas.

The hypertension risk is also related to marital status, as widowed individuals were identified to be more at risk in rural areas, which was higher for married people in urban areas. Rural communities tend to have a thicker culture, particularly relating to marriage at a young age. ${ }^{12}$ Therefore, parents from villages and less economically inclined, leading to the assumption that marrying off children reduces the burden, which possibly helps. The negative impact is divorce, resulting from the lack of awareness regarding household responsibilities, often related to emotional maturity, increased maternal mortality rate, loss of educational opportunities and others. ${ }^{21}$ In addition, individuals with a marital status have an obligation to the family and the environment, which sometimes triggers stress and increases blood pressure. ${ }^{22}$

Stressful conditions are usually characterized by changes in appetite, leading to the manifestation of obesity and excess weight, resulting from the release of stress on food, while people with poor nutritional status further reduce in energy. ${ }^{23} \mathrm{In}$ addition, irregular dietary patterns have also been identified as risk factors in nutritional and food problems, leading to an imbalance of undernutrition and over nutrition. ${ }^{24}$ Moreover, urban communities tend to work with limited mobility, including the practice of being in front of a computer, while heavier activities in the nature of farming is conducted more in rural settlements. Hence, a modification in dietary patterns encourages the incidence of obesity following urbanization habits, including the consumption of fast foods containing fat, salt and high level of calories. ${ }^{25}$

Smoking has been adopted as an ineffective stress management strategy liked by many people, despite the negative effects. However, there is a marked upsurfe in the statistics of smokers, especially in the young population, due to the assumption that it possesses calming functions in anxious and stressful situations. ${ }^{26}$ Based on this research, the risk of hypertension is enhanced in individuals with a history of tobacco consumption in urban areas, while no correlation was identified in rural communities. However, studies have shown the capacity for smoking to ease anxiety, following the effects of nicotine present, although the incidence of dependence consequently increases stress levels in an individual. This practice in urban areas are not only based on necessity and pressure of friend at work, but also as a form of prestige, trends and a condition in social interactions. Conversely, life demands and stress levels are lesser in rural areas, making people living in the urban regions vent stresses to negative activities, including smoking, which is also supported by the continuously fading religious life. ${ }^{12}$

\section{CONCLUSIONS AND RECCOMENDA- TION}

Based on the result and discussion, psychosocial stress was identified as a risk factor for the incidence of hypertension, due to the following control variables, including age, sex, education, 
economic, and marital status, as well as Body Mass Index (BMI) in rural communities. However, a similar study outcome was obtained in urban areas, which was based on the aforementioned variables, alongside a history of tobacco consumption. Hence, there is a need to take preventive actions in communities, through the implementation of healthy lifestyle, balanced dieting and the regular control the blood pressure. The quality improvement of Integrated Assistance Posts (Posbindu) is also possibly by providing interventions techniques that reduce stress, including its management, the practice of relaxation techniques and related health education, consequently enhancing the detection of hypertension threats caused by stress.

\section{REFERENCES}

1. WHO. Hypertension. [Online]. 2015. Available at: http://www.who.int/topics/hypertension/en/

2. Kemenkes RI. Hasil Utama Riset Kesehatan Dasar (Riskesdas) 2018. Jakarta: Kementerian Kesehatan RI; 2018.

3. Bhelkar S, Deshpande S, Mankar S \& Hiwarkar. Association between Stress and Hypertension among Adults More Than 30 Years: A Case-Control Study. National Journal of Community Medicine. 2018;9(6):430 433.

4. Peltzer K, Pengpid S. The Prevalence and Social Determinants of Hypertension among Adults in Indonesia: A Cross-Sectional Population-Based National Survey. International Journal of Hypertension. 2018;2018:1-9.

5. V. M. A, E., S, G., R, U. Prevalence of Hypertension and its Association with Psychosocial Factors among Old Age Home Inmates in an Urban Area of Kancheepuram District, Tamil Nadu. International Journal of Community Medicine and Public Health. 2017;4(10):3712.-3720.

6. Daştan I, Erem A, Çetinkaya V. Urban and Rural Differences in Hypertension Risk Factors in Turkey. The Anatolian Journal of Cardiology. 2017;18(1):39-47.

7. Oktavia F, Martini S. Besar Risiko Kejadian Hipertensi Berdasarkan Faktor Perilaku pada Tentara Nasional Indonesia (TNI).
Media Kesehatan Masyarakat Indonesia. 2016;12(3):127-136.

8. Noorbala A.A, Faghihzadeh S, Kamali K, Yazdi SAB, Hajebi A, Mousavi M.T, et al. Mental Health Survey of the Iranian adult Population in 2015. Archives of Iranian Medicine. 2017;20(3):128-134.

9. Sihombing, M. Faktor yang Berhubungan dengan Hipertensi pada Penduduk Indonesia yang Menderita Diabetes Melitus (Data Riskesdas 2013). Buletin Penelitian Kesehatan. 2017;45(1):53-64.

10. Harfiantoko M, Kurnia E. Derajat Hipertensi Mempengaruhi Kualitas Tidur dan Stres Psikososial. Jurnal STIKES RS Baptis Kediri. 2013;6(2):1-12.

11. Ponto L. Hubungan antara Obesitas, Konsumsi Natrium, dan Stres dengan Kejadian Hipertensi pada Orang Dewasa di Puskesmas Tompaso Kabupaten Minahasa. Jurnal Fakultas Kesehatan Masyarakat Universitas Sam Ratulangi. 2016;4(2):115-129.

12. Soerjono S. Sosiologi Suatu Pengantar. Jakarta: Grafindo Pustaka; 2009.

13. Sundari, Lilies, Bangsawan M. Faktor-Faktor yang Berhubungan dengan Kejadian Hipertensi. Jurnal Keperawatan. 2015;11(2):216223.

14. Wiraputra A. Stres pada Penduduk Lanjut Usia yang Menderita Hipertensi di Wilayah Kerja Puskesmas Tabanan Ii Kabupaten Tabanan Periode September-Oktober 2013. Intisari Sains Medis. 2015;3(1):51-57.

15. Rianti, Dwi ED. Analisis Kebiasaan Merokok terhadap Hipertensi pada Berbagai Kegiatan Aktifitas. INOVASI. 2018;20(2):95-103.

16. Peer N, Steyn K, Lombard C, Gwebushe N, Levitt N. A High Burden of Hypertension in the Urban Black Population of Cape Town: The Cardiovascular Risk in Black South Africans (CRIBSA) Study. PLoS One. 2013;8(11):1-11.

17. Sutanto. Cegah dan Tangkal Penyakit Modern. Yogyakarta: Andi Yogyakarta; 2010.

18. Bastable SB. Perawat Sebagai Pendidik: Prinsip-Prinsip Pembelajaran dan Pengajaran. Jakarta: EGC; 2012.

19. Vito B, Krisnani H, Resnawaty R. Kesenjangan Pendidikan Desa dan Kota. Prosiding 
Penelitian \& Pengabdian Kepada Masyarakat. 2015;2(2):147-300.

20. Andria KM. Hubungan antara Perilaku Olahraga, Stress dan Pola Makan dengan Tingkat Hipertensi pada Lanjut Usia di Posyandu Lansia Kelurahan Gebang Putih Kecamatan Sukolilo Kota Surabaya. Jurnal Promkes. 2013;1(2):111-117.

21. Mai, Tiara J. Tinjauan Yuridis terhadap Perkawinan Anak di Bawah Umur di Lihat dari Sudut Pandang Undang-Undang Nomor 1 Tahun 1974. Lex Crim. 2019;8(4):114-121.

22. Heriyanto. Analisis Sosial Ekonomi yang Mempengaruhi Tingkat Fertilitas di Kota Balikpapan. Samarinda: Fakultas Ekonomi Universitas Mulawarman; 2011.

23. Nadeak TA, Siagian A, Sudaryati E. Hubungan Status Stress Psikososial dengan Kon- sumsi Makanan dan Status Gizi Siswa SMU Methodist-8 Medan. Jurnal Gizi, Kesehatan Reproduksi, dan Epidemiologi. 2013;2(6):1-8.

24. Irianto K. Gizi Seimbang dalam Kesehatan Reproduksi. Bandung: Alfabeta; 2014. pp. 1689-1699.

25. Tahapary DL, De Ruiter K, Kurniawan F, Djuardi Y, Wang Y, Nurdin SME, et al. Impact of Rural-Urban Environment on Metabolic Profile and Response to a 5-Day High-Fat Diet. Scientific Reports. 2018;8(8149):1-9.

26. Bawuna NH, Rottie J, dan Onibala F. Hubungan Antara Tingkat Stres dengan Perilaku Merokok pada Mahasiswa Fakultas Teknik Universitas Sam Ratulangi. Jurnal Keperawatan UNSRAT. 2017;5(2):1-8. 